\title{
SOCIOLOGICAL KNOWLEDGE AND IDEOLOGY IN THE GERMAN DEMOCRATIC REPUBLIC: THE INSTITUTIONALIZATION PROCESSES OF A DISCIPLINE
}

\author{
BARBARA GRÜNING ${ }^{1}$ \\ ${ }^{1}$ University of Milan-Bicocca, Department of Sociology and Social Research, Via Bicocca degli Arcim- \\ boldi 8, 20126 Milan, Italy. ORCID: 0000-0002-2463-8880, Email: barbara.gruning@unimib.it
}

ABSTRACT: This article analyzes the dissemination of sociological knowledge in the social sciences and humanities ( $\mathrm{SSH}$ ) and other fields of cultural production in the German Democratic Republic (GDR), from the early postwar period to German reunification. In this regard, I investigate the relationships between sociology and politics, taking into account the specific contexts of the GDR-State and the institutionalization processes of these disciplines. To prevent a deterministic understanding of political power on academic and scientific systems, I adopt the Bourdieusian concept of field (cf. Bourdieu 1966; 1984; 1985; Bourdieu and Wacquant 1992; Bourdieu and Boltanski 2008). This concept allows me to highlight how the relationship between the academic and political fields changed over time by simultaneously looking at the influences of political, cultural, social and economic transformations of GDR society on the political goals of the GDR-State and the strategies of sociologists within the broader field of production of sociological knowledge.

KEYWORDS: ideology; academic field; GDR; sociological knowledge; field of cultural production; political culture

\section{INTRODUCTION}

The core of this work is an exploration of the production, reception and circulation of sociological knowledge in the German Democratic Republic (GDR) in light of the institutionalization processes (cf. on the topic: Whitley 1974; Stölting 1990; Brown 1993; Fleck, Karadi and Düller 2018) of sociology from the early postwar phase (1946) until the collapse of the GDR-State in 1990.

This perspective entails two interlaced levels of analysis. The first level concerns the inception and institutionalization of sociology as a scientific discipline in parallel to the genesis and development of the GDR-State. This means, in turn, taking into ac- 
count: (1) the political, cultural and symbolic functions of the academic and scientific systems over time; (2) the position sociology occupied within the hierarchy of social science and humanities (SSH) disciplines; (3) the criteria adopted for evaluating sociological works and their influences on the academic and intellectual trajectories of sociologists. The second level involves more broadly investigating how sociological knowledge was produced, standardized, applied, evaluated and legitimized over time, not only within the sociological field, but also in other fields of cultural production and the political field (cf. Baert and Shipman, 2011; Bourdieu, 1966, 1975, 1984, 2001; Bourdieu, Chamboredon and Passeron 1968; Bourdieu and Boltanski 2008; Camic 1992; Camic, Gross and Lamont 2002; Chapoulie 2001, 2009; Collins, 2011; Gross, 2008; Heilbron 1995; Ringer, 1990; Santoro 2013; Steinmetz 2017).

As I will discuss below, this perspective enables me to avoid a deterministic understanding of the influence of ideology on the production of sociological knowledge. Hence, after illustrating the research methods used, I will first reframe the question of the relationship between ideology and sociological knowledge by considering the social conditions of its production, reception and circulation (cf. Bourdieu 2002). As a second step, I will try to sketch the field of production of sociological knowledge on the basis of different forms of political, academic and scientific capitals (cf. Bourdieu 1984; 2000). I will then relate the distribution of the positions of the different collective and individual actors which structure the social space of the field to the distribution of the different forms of sociological knowledge which, instead, structure its symbolic space (cf. Bourdieu 1994). Finally, I will present an overview of the different institutionalization processes of sociology and sociological knowledge in the GDR, in light of the broader political, cultural and economic changes which affected institutional and cultural life in the GDR-State and which, in turn, had an impact on the organization and hierarchization of knowledge within the academic and scientific fields.

\section{RESEARCH METHODOLOGY}

This paper is based on the secondary literature on sociology, the social sciences and the academic system in the GDR (cf. Adler and Reißig 1991; Bafoil 1991; Begemann 1974; Bertram 1997; Burrichter and Diesener 2002; Friedrich and Griese 1991; Friedrich, Förster and Starke 1999; Greenfeld 1988; Hechler and Pasternack 2015; Koch 1976; Koch 1997; Ludz 1971; 1972; Pasternack 2016; Peter 1991; Schäfers 1995; Schmickl 1973; Sparschuh and Koch 1997; Sparschuh and Simon 1992; Timmermann 1990; Wagner 1989; Weidig 1997; Weymann 1972) ${ }^{1}$ as well as on empirical research

\footnotetext{
${ }^{1}$ The secondary literature on the GDR-social sciences can be divided into two main historical phases: in the early 1970s, thanks to the attention of some sociologists of the German Federal Republic, and in the 1990s as a result of the Reunification processes. Whereas in the 1970s the attention was mostly drawn to the contents and topics of the 'marxist sociology', in the 1990s it was mostly drawn to the relationship between ideology, politics and sociology. We can identify here two main research streams: the first one focuses on the question of whether and to what extent sociology in the GDR was a scientific discipline (see in particular: Peter 1991); the second one pays closer attention to individual and collective academic trajectories of sociologists and social scientists in the disciplinary field (see in particular:
} 
carried out in 2017. Part of the secondary literature and some of the documentary analysis of sociological works and works involving sociological concepts were collected in 2016. The empirical investigation was based on archival research methodology and semi-structured in-depth interviews. The archival research was carried out at the Bundesarchiv and the Humboldt-Universitätsarchiv in Berlin. The research materials included more than 300 documents produced by the Ministry for Universities, The Akademie der Gesellschaftswissenschaften, The Akademie der Wissenschaften, Directors of academic and scientific institutes, as well as professors who were either involved in political decision-making for university and academic evaluation processes or in reporting research findings. The documents included materials of very different types: legislative proposals for the foundation of new institutes; exchanges of letters; curricula reforms; proposals for central research plans; research reports, conference reports; evaluations of academic dissertations; curricula of professors and research assistants, etc. As I point out in the following sections, the analysis of the archival materials allowed me to detect the primary changes in the institutionalization processes of sociology and sociological knowledge, especially by: (1) identifying, over time, the chain of actors, rules and criteria defining the decision-making procedures for the institutionalization of sociology as a discipline and the production and circulation of sociological knowledge; (2) pinpointing different career patterns of sociologists (and social science scholars) over time; (3) tracing cultural and linguistic changes in the content of sociological programs, research projects and curricula.

Furthermore, between October 2015 and November 2017, ${ }^{2}$ seven in-depth interviews were carried out with social and cultural science scholars who were born in the 1940 s and early 1950s. For various reasons, it was difficult to retrace the sociologists of the 'first generation'. In any case, the choice of interviewing both social and cultural science scholars enabled me to explore how sociological concepts and theories circulated even outside of the 'institutionalized' sociological field (cf. Santoro, Gallelli and Grüning 2018). More generally, the analysis of the interviews highlighted a twofold structure of formal and informal power relationships in the field of sociological knowledge production, which also affected the ways of teaching, organizing and doing research.

\section{SOME GENERAL IDEAS REGARDING THE SOCIAL CONDITIONS AND BOUNDARIES OF SOCIOLOGY IN THE GDR}

Before exploring the different phases and processes of the institutionalization of sociology in the GDR and their implications for the production, reception and dissemination of sociological knowledge, let me first make this point: the fact that sociological production was controlled by the GDR-State does not inherently mean that it mirrored the state ideology. Indeed, to claim otherwise would risk leading to tauto-

Sparschuh and Koch 1997).

${ }^{2}$ Irene Dölling (October 2015); Dieter Wiedemann (September 2016); Peter Wicke (March 2017); Thomas Edeling (October 2017); Jutte Begenau (November 2017); Hildegard Nickel (November 2017); Vera Sparschuh (November 2017). 
logical conclusions, without bringing anything new. Thus, to better understand the entanglement between sociological knowledge and ideology in the German socialist state, three crucial aspects need to be taken into account.

First, politics played a pivotal role in defining what 'sociology' was and what it should investigate, mostly according to its political goals rather than its ideology. This aspect regarded the functioning of GDR cultural politics more generally (cf. Wehling 1989). Thus, while Marxist-Leninist ideology was the main legitimation source for the German Socialist State, the translation of ideological principles into political guidelines for governing society was primarily a pragmatic political matter as well as a difficult task. Furthermore, the pragmatic interpretation of ideological principles changed over time, depending on the broader social, economic and cultural (national and international) transformations affecting GDR society. It follows that 'Marxist-Leninist ideology' cannot be interpreted as a 'granite block' as its influence on the making of sociology was always mediated by the current political objectives. This perspective also allows us to better understand how the influence of ideology on sociological production changed over time, and why, as I will better argue later, in the 1950s sociology almost 'disappeared' only to 'reappear' later in the 1960s.

Second, the processing and publication of sociological work involved a chain of individual and collective actors working in different social fields (political, academic, scientific), holding different social positions, fitting different social roles and participating in different formal and informal networks. ${ }^{3}$ Thus, while it is true that the bureaucratic functioning of both the scientific and political systems followed standardized procedures, at the same time, every related decision, for example, regarding publication (what might be published), depended on the co-existing informal network of relationships which enabled a certain degree of 'negotiation' by sociologists. ${ }^{4}$ As a result, it is difficult to understand in general terms whether and when ideological statements played a role in the decision-making chain for preventing the dissemination of individual sociological texts and, vice versa, when sociologists and social science scholars were able to apply certain strategies for avoiding censorship. ${ }^{5}$

Third, the understanding of what should be considered a 'sociological work' varied over time. Following Bourdieu's understanding of the academic field, its own logics and internal structure (1984), we can identify three interwoven factors: (a) the changing political situation of GDR society, that is, the changing political goals of the state; (b) the different academic socialization of sociologists according to their generation; (c) the orientation of individual scholars and (networks of scholars) towards either orthodox or heterodox criteria, depending on their specific scientific trajectories, research topics, intellectual/scientific networks and experiences (in the workplace, in the GDR and even abroad).

The latter point entails, however, a further sticking point. Indeed, most GDR so-

\footnotetext{
${ }^{3}$ See on the importance of networks in the academic and scientific fields: Bourdieu 1994; Crossley 2010; Moody 2004.

${ }^{4}$ Interviews with: Peter Wicke; Irene Dölling; Hildegard Nickel.

${ }^{5}$ Interviews with: Dieter Wiedemann; Peter Wicke; Thomas Edeling.
} 
ciological texts did not circulate in the public sphere, but were either vertraulich or vertrauliche Dienstsache, that is, for 'secret' uses. ${ }^{6}$ Then, by comparing the 'secret' and 'public' sociological texts, two important differences can be observed which regard: 1. the symbolic and/or social-academic capital of the author; 2 . the kind of content proposed in the work (theory, methodology, empirical findings). Sociological texts published in the GDR were mainly preparatory textbooks for studying the discipline. They had, therefore, either a methodological or a theoretical character, even though theories were strongly shaped by the GDR ideology (or imported by the official sociology of the Soviet Union). Conversely, vertraulich sociological texts mainly concerned research findings. The applied character of these texts for social-political functions was stressed by the adjective concrete.

Nevertheless, as three interviewees pointed out, ${ }^{7}$ since empirical research was mainly addressed to politicians and was 'secret' precisely for this reason, making their ideological structure and semantics explicit was not required, whereas a certain level of theorization was, in some ways, practicable. Of course, theorizing was possible only by adopting specific stylistic strategies of writing whereby, for example, 'foreign' (i.e., Western) sociological concepts needed to be adapted to the linguistic utterances which were politically acceptable. In other words, in the GDR, sociology was politicized in two different ways. On the one hand, sociological research was useful for pragmatic political goals. However, in order not to publicly counter the representation of social reality propagated by the political elite, the findings of this research could not be published. On the other hand, the public sociological texts were strongly ideologized as they were intended to contribute to the formal education of students.

Summing up, by focusing on the social conditions of the production, reception and circulation of sociological knowledge, a complex entanglement between the political and academic/scientific fields and the actors operating in them emerges. This entanglement is especially evident if we consider, for example: the mixed scientific-political character of various institutions, the fact that academic curricula also included participation in political activities (even if the importance of this participation diminished over time), and the fact that it was even possible to obtain a PhD or a qualification from political institutions. ${ }^{8}$ Thus, as my interview partners stated, ${ }^{9}$ the space of academic autonomy for sociologists changed according to where they worked. Furthermore, the cognitive and cultural identity of sociology (cf. Lepenies 1981) was primarily

\footnotetext{
${ }^{6}$ Source: 'Merkblatt zum Umgang mit den Ergebnissen der zentralen soziologischen Forschungen', Institut für Gesellschaftswissenschaften beim Zentralkomitee der SED, March 23rd, 1965 (in Bundesarchiv Berlin).

${ }^{7}$ Interviews with: Peter Wicke; Dieter Wiedemann; Hildegard Nickel.

${ }^{8}$ The observation is based on the curricula of and/or documentation about: Alfred Vierkandt (18671953); Heinz Maus (1911-1978); Herman Scheler (1911-?); Kurt Brauentheuer (1913-1975); Arthur Meier (1932-); Günther Mielke (1935 - ?); Dieter Dohnke (1938 -); Helmut Rabe (?); Günter Gütsche (1939-); Wulfram Speigner (1940-1991); Holger Michaelis (1942-); Manfred Lindtner (1944-); Marianne Schulz (1946-); Jutta Begenau (1949-); Ralph Elmar Lungwitz (1951 -); Klaus Klinzing (?) (Humboldt-Archiv Berlin).

${ }^{9}$ Interviews with: Vera Sparschuh; Hildegard Nickel; Jutte Begenau; Peter Wicke; Dieter Wiedemann.
} 
defined by the political instrumentalization of 'concrete sociological research' rather than its ideologization. Nevertheless, in the first phase of the discipline's inception, most of the founders and initiators of sociology in the GDR, who also contributed to its re-institutionalization in the 1960 s, were convinced that sociology also had a political mission. Conversely, the sociologists of the next generation preferred to keep their distance from the political sphere. While this allowed them to preserve a certain degree of freedom in their research activities, it also prevented advancement in their academic careers (cf. Sparschuh and Koch 1997). ${ }^{10}$ Not least, the separation between a pragmatic political goal and an 'ideology of facade', as we will better see in the following sections, entailed that sociology always occupied a low position in the hierarchy of SS-disciplines.

Hence, in what follows, in order to highlight how ideology and contemporary political goals contributed over time to the definition of the hierarchy of both SS-disciplines and sociological issues, I will first take into account how they affected the positioning and practices of institutions, organizations, research groups and individual actors in the field of producing sociological knowledge. This perspective ensures a closer examination of the different institutionalization processes of sociology rather than a holistic view of the influence and control of the GDR-State on the whole academic system, and not least on the institutionalization of sociology.

\section{A SKETCH OF THE SOCIOLOGICAL FIELD IN THE GDR}

Before illustrating the different institutionalization phases of sociology in the GDR, it is important to identify which actors played a role in these processes and what kind of 'sociological knowledge' they produced.

Scholars interested in the development of sociology in the GDR have mainly focused on the institutionalization of the official GDR sociology and, thereby, on the construction of a specific corpus of knowledge close to the interests and ideology of the state within specific social science academic and political structures. ${ }^{11}$

This perspective presents, however, two sticking points. First, little attention has been paid until now to the production and dissemination of sociological knowledge outside the core disciplines of the social science field. Second, the entanglement between political, scientific and academic actors in the process of making sociological knowledge risks being reduced to a deterministic relationship between the political elite and scholars in which the former played the role of decision-makers and social controllers, whereas the latter were performers of teaching and research programs, whose topics, theories and methodologies were established by the 'top'. What is puzzling is that the 'political elite' and the 'scholars' seem to be juxtaposed in terms of 'structure' and 'action'. In this regard, even changes concerning the organization and contents of sociological knowledge may be interpreted as only deriving, in Luhmann's

\footnotetext{
${ }^{10}$ Interviews with: Vera Sparschuh (November 2018); Thomas Edeling (October 2018); Hildegard Nickel (November 2018); Jutte Begenau (November 2018); Peter Wicke (March 2017).

${ }^{11}$ In the GDR, as we will see later, the social sciences were renamed as Gesellschaftswissenschaften, in order to differentiate them from the Western [bourgeois] tradition of the social sciences.
} 
terms (1997), from the interaction between the political structure (or system) and the environment.

The frame I propose does not underestimate the importance of structural constraints on individual actions, but offers a better reading of the structure-agency interplay. Hence, by using the Bourdieusian concept of 'field' (cf. Bourdieu and Wacquant 1992) as an analytic category, I will consider the processes of the production, reception and circulation of sociological knowledge in light of the interdependence between the social space of the actors involved in making 'sociology' and the symbolic space defined by the distribution of the different sociological outputs.

By starting from the latter, we can identify three main groups of 'objectified' forms of sociological knowledge. The main corpus in terms of political and academic prestige was constituted by texts recognizable as belonging to the canon of 'GDR sociology'. Thus, these texts represented the official political viewpoint of the discipline and presented a high level of ideologization, although a large part of the official sociological corpus was also devoted to methodological questions and techniques. The second and most conspicuous group of works consists of unpublished research projects and papers which, in turn, can be divided into two subgroups: those produced for internal scientific/academic research groups, and those produced for politicians. The third group is constituted by works produced by academic scholars who did not work in (scientific, academic or political) institutes where sociology was officially taught. What distinguishes this body of work are not only the sociological concepts and theories that were used within other disciplinary frameworks but also that they were partially 'alternative' to the canonical concepts and theories used by GDR sociology and also borrowed from international (Western) sociologists. Hence, we can recognize in this corpus of works closer attention to the cultural aspects and phenomena of society. ${ }^{12}$ More importantly, parts of these texts were also published.

To graphically depict the symbolic space of GDR sociological works (embedding different forms of sociological knowledge), we can imagine it as being formed by two perpendicular graduated axes of political and academic capitals. ${ }^{13}$ Along the horizontal axis we find different degrees of academic capital as a result of two criteria: the relevance of the corpus of works for the institutionalization of sociology in the GDR and the international prestige of the authors, that is, the (international) recognition of their scientific value. Instead, along the vertical axis, we find different degrees of

\footnotetext{
${ }^{12}$ Two of my interview partners correspond to this profile: Peter Wicke, who was already well-known at an international level during the GDR for his studies on popular music; and Irene Dölling, who first imported Bourdieu into the GDR.

${ }^{13}$ The reconstruction is based on the interviews carried out with my interview-partners; on the content and stylistic analysis of some of the main published works of the GDR [AA.VV. 1981; AA.VV. 1988; Adler, Jetzschmann and Kretzschmar 1977; Autorenkollektiv 1975; Autorenkollekti 1985; Bisky 1980; Bohring and Taubert 1970; Bohring and Braunreuther 1965; Bollhagen 1966a; 1966b; Bradter 1966; Braunreuther 1962; Dölling 1986; Eichhorn et al. 1969; Friedrich and Hoffmann 1986; Kuczynski 1987; Meier 1974; Nolepa and Steitz 1975; Petzoldt 1988; Weissel 1980; Wicke 1987; Wiedemann 1983; Wiedemann and Griebel 1980; Zentralhaus für Kulturarbeit der DDR 1978] and of the non published research reports filed in the Bundesarchiv Berlin(period: 1964 -1989).
} 
political capital related to the distance of a work from GDR ideology. In this regard, we can pinpoint four main benchmarks (in order, from more to less ideologized): works mirroring GDR ideology; works related to GDR political goals; works contrasting (explicitly or implicitly) with the GDR representation of social reality; works contrasting with the ideological positioning of the GDR in the international space of the Cold War (i.e., 'socialist' vs 'bourgeois' sociology). In Figure 1, we can see a sketch of how the three groups of sociological works can be distributed along the two axes.

Figure 1. The field of production of sociological knowledge: the symbolic space

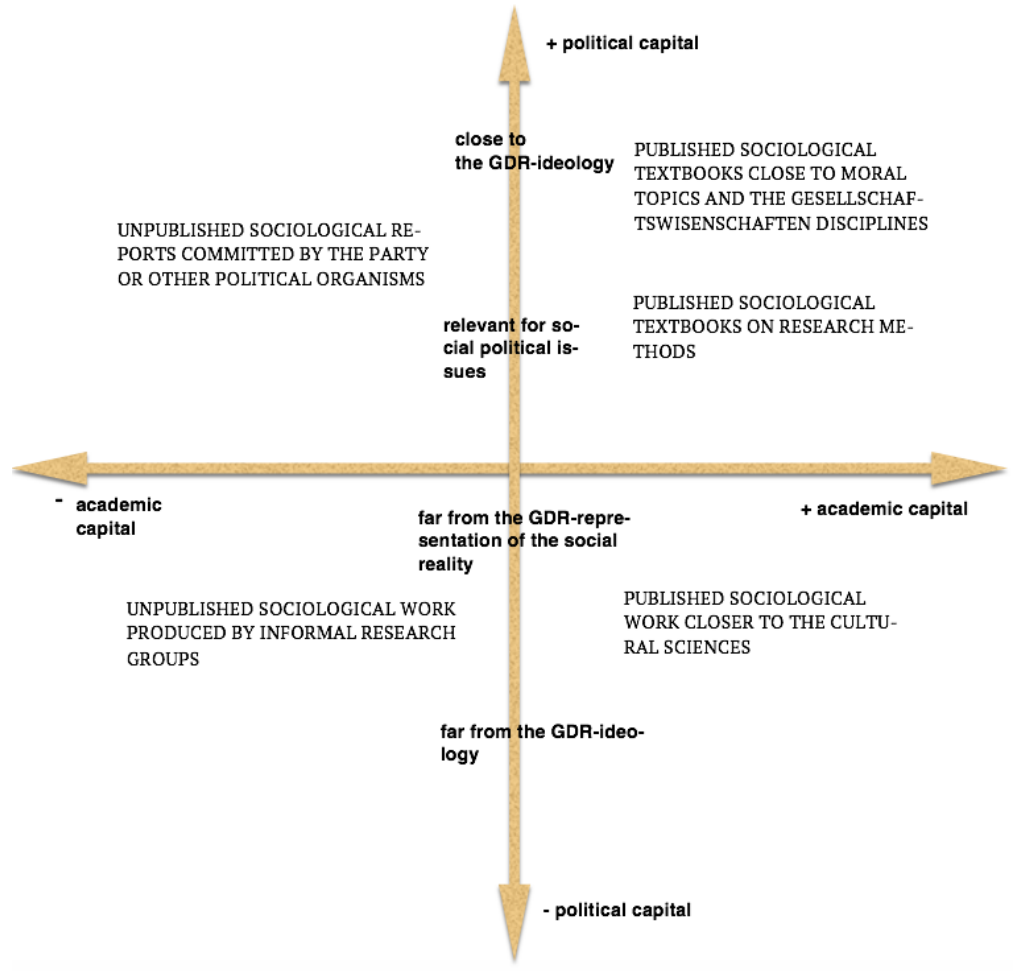

Source: own elaboration

The social space was constituted by the power relationships among the individual and collective actors involved in the production, circulation and reception of sociology. In terms of collective actors, I consider those institutions and organizations in which scholars acted and which not only formally ruled and defined the contents and understanding of sociology, but also influenced the space of possibility for individual actors to deploy 'innovative' practices and build informal networks through which to accumulate other forms of capital (especially symbolic capital).

As a first step, I will consider the collective actors according to their 'political' relevance by starting from those with the highest degree of political capital (cf. Bourdieu 2000): (1) the political office of the Central Committee of the Socialist Unity Party of Germany (Politbüros des Zentralkomitee der SED); ${ }^{14}$ (2) the Ministry for Universities (until the 1960s, the Ministry for National Education); (3) trade unions and political organizations (i.e., FDJ); ${ }^{15}$ (4) scientific institutions of social sciences directly ruled

\footnotetext{
${ }^{14}$ Socialist Unity Party of Germany, Sozialistische Einheitspartei Deutschland (SED).

${ }^{15}$ The Freie deutsche Jugend, that is, the ‘Free German Youth' association, was an official political orga-
} 
by the Party (i.e., Die Akademie für Gesellschaftswissenschaften beim ZK der SED, that is, the Academy for Social Sciences of the Central Committee of the Party); (5) universities and high schools; (6) 'nonpolitical' and non academic research institutes (i.e., Die Akademie der Wissenschaften; Das Zentralinstitut für Jugendforschung); (7) factories; (8) further social collective public organizations/institutions (i.e., the 'Radio'). Nevertheless, in considering the positioning of the different collective actors, we should further consider their academic/scientific capitals, as depicted in Figure 2.

Figure 2. The field of production of sociological Knowledge in the GDR: the social space

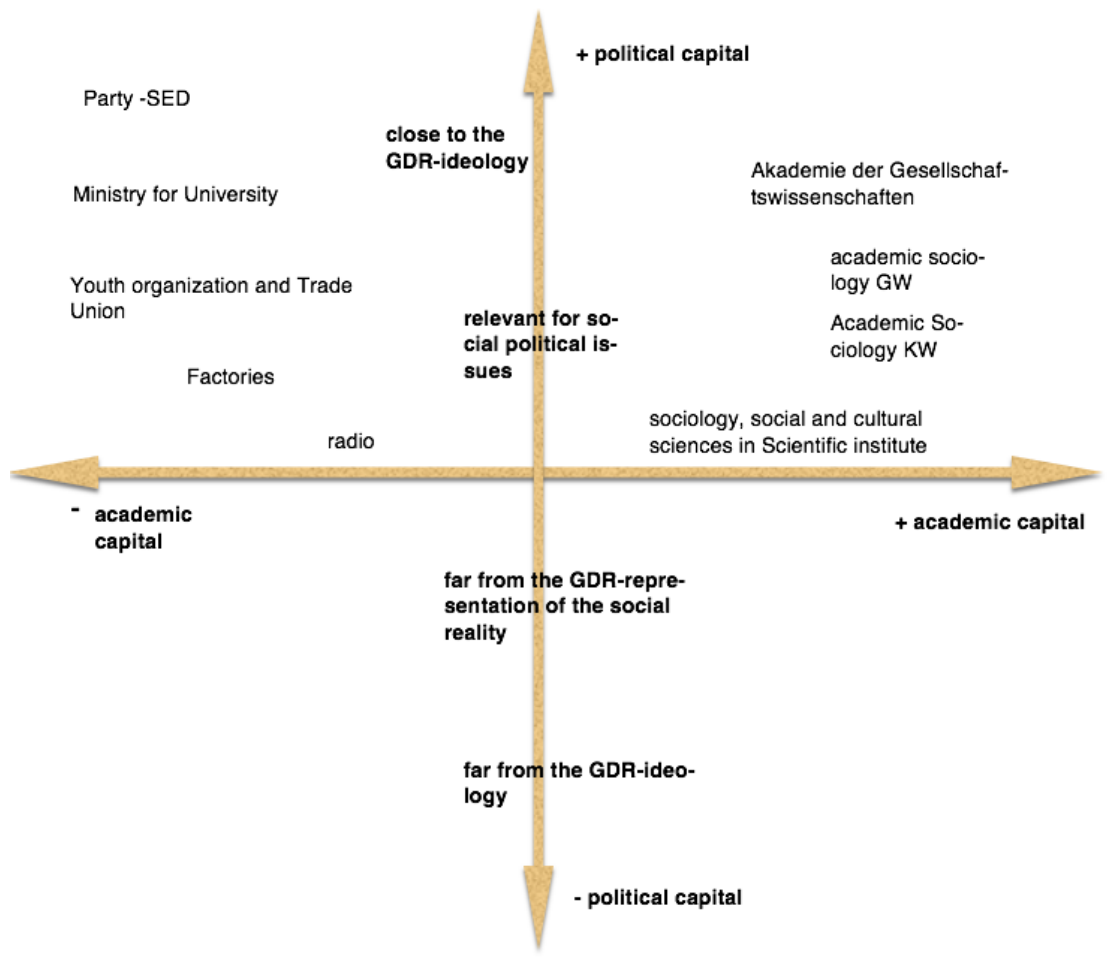

Source: own elaboration

The main aspect to stress is that the different degrees of closeness to the "political elite' entailed different degrees of scientific and academic autonomy. However, as mentioned above, distinguishing between ideological and political constraints is fundamental not only in order to understand the different kinds of sociological knowledge produced in the GDR, but also to define the space of actions of both the collective and individual actors.

Let me start from the scientific institutes. The fact that they were more distant than universities from the core of the political sphere meant, first, less ideological pressure and, vice versa, greater autonomy in deciding their own research fields, structuring their own scientific work, and forming informal networks. ${ }^{16}$ On the other hand, because of their scientific values, their research was especially desired by the political elite to understand the cultural and social transformations of GDR society. As a result,

nization for the young people of the GDR.

${ }^{16}$ This aspect has been stressed by all my interview-partners. 
most of the scientific works were not issued publicly. Furthermore, as the case of the Leipzig Central Institute for Youth Research highlights, in Leipzig a mutual mistrust between the representatives of the Ministry for National Education and the directors and researchers working at the institute existed. A further important factor in determining the degree of autonomy of the scientific institutes was the geographical distance from Berlin as Berlin was the political bureaucratic centre of the GDR; being physically distant from the capital corresponded to being more distant from political control. ${ }^{17}$

Universities, then, had less political autonomy than research institutes, also because of their educative role. In any case, the space of autonomy for academic sociologists could change according to where they worked. As for the scientific institutes, the geographic distance of universities from Berlin (i.e., from the 'political centre') was crucial, especially for the older universities, such as the University of Jena, which tried to maintain their academic traditions in terms of programs, practices and habitus, as emerged from political reports. ${ }^{18}$ Furthermore, research/teaching autonomy also depended on the institute/faculty with which sociologists were affiliated, according to the hierarchy of disciplines defined by the State. For what concerns the macro-area of the social sciences, it is important to stress how the university reforms carried out after 1951 aimed at consolidating the leading position of the new Gesellschaftswissenschaften (science of society) in the academic system. In Gesellschaftswissenschaften, the core and more ideological disciplines were 'dialectical materialism', 'historical materialism', political economy, 'history of the workers' movement' (with some variations in the name over time) and scientific communism, which were compulsory for each degree course (also in the natural sciences). Philosophy was considered a 'social science discipline', and until the mid-1960s was 'reduced' to dialectical and historical materialism (see after the sociological curricula). Both philosophy and economics, then, accomplished an ideological function. The fact that academic sociology initially developed within the faculties of philosophy and economics highlights its subordination to these two more ideologized disciplines, even if sociology was mainly (and politically) considered only an applied SS-discipline. On the other hand, from the mid1960 s, sociology began to also be taught in other institutes and degree courses, for example Kulturwissenschaften or medicine, where the ideological pressure was lower than in philosophical institutes. ${ }^{19}$

Factories and radio were two further important spaces where sociological knowledge was produced. Nevertheless, they presented a different internal structure of political control and different research areas with different symbolic relevance. Indeed, over time, the sociology of work became a pivotal research current for the discipline, whereas research related to cultural issues, tastes and lifestyles gained increasing at-

\footnotetext{
${ }^{17}$ See, in this regard, the interview with Walter Friedrich, founder and Director of the Zentralinstitut für Jugendforschung from 1966 to 1990 (in: Sparschuh and Koch 1997).

${ }^{18}$ Source: 'Bericht über den Besuch der Universität Jena von 16. bis 17. Mai 1950', Mai 27th, 1950 (in Bundesarchiv Berlin).

${ }^{19}$ Interviews with: Irene Dölling and Hildegard Nickel.
} 
tention only after the end of the 1960s, in parallel to the cultural-social transformations of society which especially affected the youth. ${ }^{20} \mathrm{~A}$ third factor to consider is that researchers working for the radio institution were more responsive to international (Western) influences (cf. Polgers 2000).

Last, but not least, on account of their closer relationship to the Party, political science institutes actually presented more spaces for freedom than universities. Thus, sociologists working, for example, in the Akademie für Gesellschaftswissenschaften covered a double power position within the political and academic fields and were more able to act autonomously not least, as recounted one of my interviewees, ${ }^{21}$ because as 'controllers' they were not subjected to political control. ${ }^{22}$ Furthermore, by hedging a twofold power position, they were also able to support people belonging to their informal networks in publishing their research output and to advance reform projects at higher political decision levels. Equally important for their political capital was, in some cases, their international scientific prestige (see, for example, the case of Lothar Bisky), which also entailed belonging to meaningful international networks and, in turn, especially beginning from the 1970s, giving prestige to the GDR (cf.). In this way, individual international recognition (symbolic power) could be converted into political capital for the country. This allowed them to act more freely than other scholars in organizing their scientific work (in terms of projects, publications, seminars, and so on) as long as the symbolic and political legitimation of the GDR State was not questioned.

In short, looking at the development of sociology from the lens of the Bourdieusian field offers a more complex perspective on the transformation of both the social and symbolic space of the discipline and their relationship. In this regard, by considering together both political and academic/scientific capitals, it is evident how the political control of the development of the discipline was diversified according to the subfield, institutions and specific actors towards which political control was addressed. Finally, as we will see in the next section, this gateway provides a better understanding of the various institutionalization processes of sociology in the GDR from the second half of the 1940 s to the 1990 s.

\section{THE (DE)INSTITUTIONALIZATION OF SOCIOLOGY IN THE GDR: 1946-1990}

In the following, I illustrate the (de)institutionalization processes of sociology in the GDR through three examples. The first one concerns the identification of the main

\footnotetext{
${ }^{20}$ Interviews with: Peter Wicke; Jutta Begenau and Hildegard Nickel.

${ }^{21}$ Interview with Peter Wicke (Spring 2017).

${ }^{22}$ In the interview, Wicke referred especially to Lothar Bisky. Bisky was a sociologist of culture who never taught in a social science institute. From 1966 to 1980, he worked as an assistant and later as Department Head at the Institut für Jugendforschung in Leipzig. In 1979, he became Honorarprofessor at the Humboldt University in the Faculty of Kulturwissenschaften (and not Gesellschaftsiwssneschaften). From 1980 to 1986, he was also Dozent at the Akademie für Gesellschafstwissenschaften and, from 1986, full Professor at the High School for Film and Television in Potsdam (from 1986 to 1990, he was also Rector of the school).
} 
academic, scientific and political institutional stages of this process. The second relates to the dissemination of sociological knowledge through conferences, journals and book-series. The third involves the transformation of sociological curricula from 1975 to 1988. The aim, as pointed out above, is to understand the different processes of the institutionalization of sociological knowledge in different (political, scientific, cultural) subfields of GDR society in order to better frame the relationship between sociological knowledge, ideology and politics.

1. Let me start from a general reconstruction of the (de)institutionalization processes of sociology from the end of WWII until German reunification. ${ }^{23}$

In the first postwar phase (1945-1951), the main political goal of the Soviet occupation forces before, and the GDR government later, was the denazification of the universities, that is, the expulsion of professors suspected of having been politically involved with National Socialism (cf. Burrichter and Diesener 2002). Thus, little attention was paid to reforming the university system and academic curricula. For what concerns the situation of sociology, as sketched in Table 1, the discipline had barely survived during the Nazi regime and the war. An 'anti-sociological attitude' emerged during National Socialism against the dominant 'bourgeois' sociological currents in the Weimar Republic, leading to a decrease in academic sociological teaching and positions at the university in favour, however, of a dissemination of sociological knowledge in the applied social sciences (i.e., demography, spatial studies, etc., cf. Klingemann 1996). Even the following denazification process in the second half of the 1950s contributed to reducing the number of 'available' sociologists, as the case of Hans Freyer, who lost his Chair in Sociology at the University of Leipzig, well highlights. ${ }^{24}$ Nevertheless, the Deans of the universities were, in this transitional phase, still interested in maintaining the teaching of sociology. This is clear if we look at the case of the Humboldt Universität, where two well-known sociologists (who are now recognized as pivotal figures in the history of the discipline in Germany) were called to teach sociology: Heinz Maus, who came from West Germany, was hired as Oberassistent (Lecturer) in 1949 at the Institute for Political and Social Problems of the Present Time (Institut für politische und soziale Probleme der Gegenwart), and Alfred

\footnotetext{
${ }^{23}$ Sources: 'Einrichtung und Arbeitsweise der Pädagogischen Fakultäten', Pädagogische Fakultät der Universität Leipzig, June 1946,;'Vorlesungsplan Pädagogische Fakultät Dresden', April 9th, 1946, 'Studienplan der Universität Berlin', February 1st, 1946; 'Vorschlag zur Struktur und Arbeitsweise des Wissenschaftlichen Rates für soziologische Forschung', Abteilung für soziologische Forschung, Berlin, 28th June 1965; 'Direktive zur Weiterführung der 3. Hochschulreform im Studienjahr 1970/1971', Ministerium für Hoch- und Fachschulwesen, October 14th, 1970; 'Begründung zur Bildung eines Instituts für Soziologie an der Humboldt-Universität zu Berlin', Humboldt-Universität zu Berlin, March 13th, 1979, 'Antrag auf Gründung eines Instituts für Marxistisch-leninistische Soziologie an der Humboldt-Universität zu Berlin', Ministerium für Hoch- und Fachschulwesen, March 11th, 1979; 'Gründung des Wiss. Beirates “Marx.- len. Soziologie”, November 23rd, 1982, (in Bundesarchiv Berlin); 'Entwicklungskonzeption Marxistisch-leninistische Soziologie im Hoch- und Fachschulwesen bis 1990', Ministerium für Hoch- und Fachschulwesen, April 8th, 1988 (in Bundesarchiv Berlin).

${ }^{24}$ It is interesting to notice how the denomination 'Sociology' was also initially refused by the Nazi regime for the same reason it was refused by the GDR-State, that is because it referred to a 'bourgeois' approach to and tradition of studying society (cf. Rammstedt 1986).
} 
Vierkandt, who had retired before the end of WWII, was asked to resume the Chair in 1946. Then, in 1951, Heinz Maus's position was eliminated, and Vierkandt died in 1953 at the age of 86 years old, teaching almost until the end of his life. ${ }^{25}$

A turning point in the (de)institutionalization process of the discipline came with the university reform of 1951 which introduced a centralized academic system, limiting the autonomy of single universities and regional power by, conversely, increasing central political control. Furthermore, the reform introduced a new classification of the disciplines and a new system for evaluating them through political and ideological criteria. The newly established SS-disciplines-scientific communism, dialectical Marxism, historical Marxism and history of the workers' movement-'satisfied' the contemporary political need for social science knowledge. In other words, in this new phase in which the main political goal of the GDR-State was to build a political community (cf. Wehling 1989), social science disciplines were exclusively conceived as having an ideological function. In this regard, sociology was unnecessary but, above all, according to the Soviet interpretation, it was a 'bourgeois discipline' and therefore ideologically inappropriate. Thus, until 1956 when the Soviet Communist Party ushered in the de-Stalinization process, 'sociology' was officially a taboo. Nonetheless, from the mid-1950s onward, some scholars (i.e., Braunreuther) constituted informal sociological research groups and published essays on sociological issues, mostly of a theoretical nature.

An important step for the inception of sociology in East German universities was the introduction of a new economic system (NÖS). Indeed, the NÖS marked a shift in the political understanding and goals of the GDR towards a technocratic socialism, increasing the need for social techniques and social analysis, especially regarding the transformations of, and fluctuations in, the economic sphere (Timmermann 1990; Burrichter and Diesener 2002). ${ }^{26}$ From 1964, the institutionalization of sociology was mainly guided from the top at two levels: within the university, by introducing 'sociological sections' in the faculties of Political Economy and Philosophy, and within the apparatus, by establishing a scientific council for sociological research in the Akademie der Gesellschaftswissenschaften, with the goal of leading and controlling the genesis and development of the sociological field within and outside the academic system (Weidig 1997). However, we can pinpoint three further institutional events which gave new and different impulses to the larger growth of sociological knowledge in the GDR: the foundation of the Institut für Jugendforschung in Leipzig in 1966, thanks to the initiative of the psychologist Walter Friedrich; the creation of a sociological section within the Akademie der Wissenschaften in 1967; and the institution of two degree courses in Kulturwissenschaften in Berlin and Leipzig in 1964. Whereas the first two events underline a parallel institutionalization of the discipline within nonacademic

\footnotetext{
${ }^{25}$ Source: see the documentation on Vierkandt filed in the Universitätsarchiv of the Humboldt university of Berlin.

${ }^{26}$ Sources: ‘Entwurf: Konzeption für eine Ordnung der soziologischen Forschung in der DDR', Institut für Gesellschaftswissenschaften beim Zentralkomitee der SED, February 9th, 1965 (in Bundesarchiv Berlin). Each university should also draw up an annual report of the research activities and publications, that came under the control of the political bodies.
} 
and political institutes, the latter stressed a parallel academic institutionalization of sociology in less ideologized and politicized academic institutes and disciplinary areas, more sensitive to their 'original' disciplinary canons and/or to international scientific trends (cf. Ludz 1971; Steiner 1997).

In the 1970s, the institutionalization process of sociology was marked by the third university reform aimed at reinforcing the supremacy of the Gesellschaftswissenschaften disciplines in the hierarchy of SS-disciplines, ${ }^{27}$ and the processing of a new economic model, which redefined the social-political interest of the GDR-State towards the material and cultural life of the GDR population. These two events had a threefold effect on the institutionalization of sociology. First, they led to a reorientation of the main topics and goals of the discipline. New attention was now paid to drawing up social indicators for solving problems related to the social conditions of GDR citizens and studying their ways of life. Second, they pushed a further professionalization and technicalization of the discipline which especially affected the academic socialization of the new generation of sociologists (who began to study sociology at the end of the 1960s). This meant, above all, the development of a more pragmatic and less ideologized attitude towards the discipline. Third, through the redefinition of its political tasks, sociology increased its autonomy from the other SS-disciplines, for what concerns the definition of a specific set of knowledge (mostly related to research techniques and methods) despite the fact that it continued to be considered an 'auxiliary social science'. In this regard, we can recall the creation of an autonomous degree course in Sociology in three universities (Berlin, Halle and Leipzig) in 1975 and the foundation of an Institute for Marxist-Leninist Sociology in Berlin in 1979. On the other hand, the autonomy of sociology also increased outside the academic sphere in two different directions, one more politicized, with the creation of an autonomous Institute for Sociology at the Akademie für Gesellschaftswissenschaften in 1975, and the other more scientifically oriented, with the creation of an Institute for Sociology and Social Politics at the Akademie der Wissenschaften in 1978.

The last step in the institutionalization process of sociology was the reform of curricula in 1981/1982. As we will see later, the reform opened a short phase of experimentation within some academic institutes which was interrupted by German reunification. It can be assumed that this experimental phase was favoured by the establishment of a scientific council for Marxist-Leninist Sociology by the Ministry of Universities, which marked a formal separation between the party and institutional university politics.

Table 1 (see APPENDIX)

2. As a second step, in order to better frame the kind and degree of scientific autonomy of sociologists over time, I considered as further parameters: the organization of

\footnotetext{
${ }^{27}$ Sources: 'Entwicklungskonzeption der Aus- und Weiterbildung auf dem Gebiet der Marxistisch-leninistischen Soziologie im Hochschulwesen der DDR, 1970; 'Zentraler Forschungsplan Gesellschaftswissenschaften', January 16th, 1984, 'Zentraler Forschungsplan Gesellschaftswissenschaften', November 9th, 1984 (in Bundesarchiv Berlin).
} 
conferences $^{28}$ and the existence of sociological associations, journals and book-series. These data are indeed indicative of the ways sociological knowledge circulated across the broader (national and international) intellectual field.

With respect to the organization of conferences [tab. 2], I distinguished between: 1) conferences organized at a local level, 2) conferences organized at a national level and ruled from the top, and 3) international conferences in the GDR, as well as the participation of GDR social scientists in international conferences.

From 1956 to 1965, when sociology was no longer considered a 'taboo' nor really an object of (political) interest, conferences were mainly organized at the local level by informal research groups acting within academic and scientific institutions. However, the third conference of the research group 'Soziologie und Gesellschaft' associated with Kurt Braunreuther, which took place in 1964, and the conference on the Sociology of Religion organized in Jena in 1965 were also open to international scholars (cf. Steiner 2010). ${ }^{29}$ In 1956, GDR scholars were also invited for the first time to the international conference organized by the International Sociological Association (ISA) in Amsterdam, albeit the choice of who could participate was not merely a sociological matter. Indeed, participating in the ISA conferences primarily had an international political meaning. This clearly emerged from the political effort made so that SS-scholars could participate in the ISA conference in Washington in 1962 (one year after the building of the Berlin Wall), whereas at this stage the interest of the political elite in developing sociology within the GDR scientific system was still very low. After 1969 , the scientific council began to organize national sociological congresses whose topics mainly mirrored the political goals of the sociological research plan defined by the scientific council, Wissenschaftlicher Rat, which was part of the Academy of Social Sciences then under the control of the Central Committee of the Unitary Socialist Party. ${ }^{30}$ Only in February 1990, after the fall of the Wall, was the GDR sociological congress

\footnotetext{
28 'Entsendung einer Delegation der DDR zum IV internationalen Soziologenkongress', addressed to the section 'Science' of the central committee of the SED-party, March 31st, 1959; 'Zielsetzung des Auftretens einer DDR-Delegation auf dem V. Weltkongress der ISA', Genosse Heinze, March 19th, 1962, 'Bemerkung zu einer Arbeitstagung', Soziologie und Gesellschaft, September 18th, 1962; 'Abschrift', Association internationale de Sociologie - Comité exécutif, February 25 1963; 'Über die Tagung des soziologischen Rates am 8.7.1965', in Aktennotiz, Berlin, Juli 9th , 1965; 'Entsendung einer Delegation zum VI. Weltkongress für Soziologie in Evian', Vorlage für das Sekretariat des ZK der SED, April 20th, 1966, 'Entwurf: Außenpolitische Direktive für die Teilnahme der Soziologen der DDR am Soziologen Kongress in Evian', August 4th, 1966; 'Bericht über die Teilnahme der DDR-Delegation am VI. Weltkongress für Soziologie', September 19th, 1966 (Bundesarchiv in Berlin). For what concerns the international conferences of the ISA I mentioned here the main documents. Nevertheless, from the end of the 1950s to the end of the 1960s the political-symbolical relevance for the GDR-state in participating to the ISA-conferences is especially witnessed proved by the intense exchange of letters between political representatives of the GDr-sociology and representatives of the ISA, as well as internal exchange of letters between political representatives and scholars of sociology about the main (political) differences of the GDR-sociology from the Western sociology.

${ }^{29}$ In this phase, international participation was still limited to sociologists of socialist countries.

${ }^{30}$ This aspect has also been pointed out by my interview partners: my interview-partners: Thomas Edeling; Hildegard Nickel.
} 
co-organized by the Initiative group for the foundation of a Sociological Association, which also redefined the topics of the conference with respect to those programmed by the Wissenschaftlicher Rat.

After 1969, however, two important changes can be observed in the ways of participating in the ISA conference. First, the increasing professionalization of sociology also entailed less ideological pressure. Second, in the late 1970s and 1980s, the international scientific recognition of GDR sociologists increased. So, for example, Lothar Bisky was elected member of the Research Committee for the 'Sociology of Culture and Knowledge' in 1978, and Arthur Meier was elected member of the Executive Committee in 1982 and Vice-President of the ISA in 1986. A step towards internationalization was also evident at a local level. With the growth of the discipline's international scientific prestige (and the increasing political relevance of this scientific prestige) and its progressive autonomy from the more ideologized SS-disciplines, it became easier for sociologists to invite Western sociologists as guests at their institutes, even if this was only at a half-formal level, in the form of internal seminars and workshops. In any case, informal international networks were mainly constructed by sociologists outside of the official sociological academic institutes or by scholars of other disciplines.

Turning to the scientific sociological journals, they existed either at a local level (i.e., the 'Religionssoziologische Bulletin der Universität Jena', das Periodikum 'Jugendforschung', which for political reasons had a short life, the 'Jahrbuch für Soziologie und Sozialpolitik' edited by the Akademie der Wisenschaften, etc.), or at a national level under direct political control and used only for internal communications (i.e., 'Informationen zur soziologischen Forschung in der DDR', published by the Akademie für Gesellschaftswissenschaften beim ZK der SED' and 'Soziologische Bulletin', published by the Wissenschaftlicher Rat). Until 1990, sociologists were politically prevented from establishing their own disciplinary journal (Sparschuh and Koch 1997). They achieved this task only one month before German reunification ('Berliner Journal für Soziologie'). As a result, until the end of the GDR, the main channel for disseminating sociological knowledge was the 'Zeitschrift für Philosophie' which regularly hosted papers from national and international conferences, underlining the minor scientific importance of sociology with respect to philosophy. The overall data highlight a general poverty of sociological output in the public sphere. This fact, however, demonstrates not only a lack of scientific autonomy (from other disciplines and from politics) but also a scant regard for sociology as an ideological SS-discipline.

Table 2 (see APPENDIX)

3. The last set of data concerns the transformation of sociological curricula from the institution of the first sociological degree-courses until the end of the GDR. ${ }^{31}$

\footnotetext{
${ }^{31}$ Sources: Ministerium für Hoch- und Fachschulwesen: 'Studienplan für die Richtung Marxistisch-leninistische Soziologie', Berlin 1975; 'Lehrprogramm zur Ausbildung in der Fachrichtung Marxistisch-leninistische Soziologie zur Ausbildung in der Fachrichtung Marxistisch-leninistische Soziologie' (differentiated for more sociological and SS-teachings), 1977; 'Bezeichnung der Vorschlage: Entwicklungskonzeption Marxistisch-leninistische Soziologie im Hochschulwesen bis 1990', Ministerium für Hoch- und Fachschulwesen, with attached 'Lehrprogramm für das Lehrgebiet. Informationsverarbe-
} 
In 1975, there were two different curricula for sociological degree-courses at the Faculties of Philosophy and Economics. In the curricula of sociology within philosophy programs [tab. 3a], sociological subjects were, on the whole, less represented than the more 'ideologized' disciplines of the Gesellschaftswissenschaften and the more specific philosophical disciplines (history of philosophy, logic, aesthetics and ethics). Furthermore, according to the curricula plan, sociological subjects were taught only in the last two years. If we look, then, at their internal division, we can still observe a certain indefiniteness about the sociological topics, with the exception of the sociology of work.

With the curricula reform in 1981-82, we find some important novelties [tab. 3b]. First, sociological curricula were divided into three profiles: philosophy, economics and scientific communism. Second, new sociological subjects were introduced. Some of these teachings were already present in other degree-courses of the Kulturwissenschaften, such as sociology of culture and sociology of education. Other subjects were, instead, entirely new and related to the political and social changes that occurred in the 1980s: an increasing interest in urban sociology was related to the urban plan promoted by the GDR-State in these years, and the teaching of military sociology followed the new wave of militarization of GDR society in the same period. Finally, the time devoted to sociological matters now surpassed the time devoted to philosophy and the Gesellschaftsiwssenschaften disciplines. Nevertheless, the first two years continued to be spent studying philosophical subjects and those related to the Gesellschaftswissenschaften.

The curricula reform of 1987 regarded only the University of Berlin. The crucial point of this reform was that the proposal came from the Director of the Institut furr ML-Soziologie, Arthur Meier. Two aspects are important to highlight. First, the existence of an autonomous Institute of Sociology at the HUB was a crucial condition not only for advancing a reform project of the curricula but also for building a professional consciousness as sociologists. This entailed not only claiming greater decisional autonomy with respect to the political sphere, but also greater scientific autonomy with respect to the other SS-disciplines. Second, this reform was also possible thanks to the prestige and charisma of Arthur Meier. In the 1970s, Meier had already founded an Institute for the Sociology of Education within the Akademie der Wissenschaften. Furthermore, his works had also been published for West German publishers and, finally, as mentioned above, in 1986 he had become Vice-President of the ISA. According to his collaborators, ${ }^{32}$ Meier managed to create a collaborative atmosphere in the Institute by orienting its research activities towards more scientific and international parameters.

itung zur Ausbildung in der Fachrichtung Marxistisch-leninistische Soziologie', in Archiv, 17th March 1982; 'Leitlinien dem 1. Studienjahr 1987/1988 einsetzenden Studienplanexperiments für die Fachrichtung Soziologie an der HUB, Institute für marxistisch-leninistische Soziologie’, Berlin, May 28th, 1987; 'Lehrprogramm für das Lehrgebiet Geschichte der Soziologie zur Ausbildung in der Fachrichtung Marxistisch-leninistische Soziologie','Lehrprogramm für das Lehrgebiet Theorie der Soziologie zur Ausbildung in der Fachrichtung Marxistisch-leninistische Soziologie', 1082/88 (in Bundesarchiv Berlin).

${ }^{32}$ Interviews with Nickel, Edeling and Begenau. 
The first suggestion presented in Meier's proposal to the Ministry of Universities was to introduce the teaching of sociological subjects from the first semester. We may further notice a substitution of the denomination of the Gesellschaftswissenschaften disciplines with 'Marxist-Leninist disciplines', which also included philosophy. This renaming is meaningful because it underlines an epistemological and symbolic separation of the more scientific SS-disciplines from those disciplines more shaped by State ideology. Secondarily, Meier proposed a twofold internal specialization, between a field of sociological subjects closer to the cultural sciences and a field of topics oriented towards the crucial questions of GDR social politics. Not least, in the proposal he increased the hours students had to devote to practical seminars, in this way reinforcing the 'praxis-oriented' character of sociology, even though it had gained more scientific legitimation than in the past.

Table 3a, 3b, 3c (see APPENDIX)

\section{CONCLUSION}

The aim of this paper was to reflect upon the production, circulation and reception of sociological knowledge in the GDR by looking at how the state politically conditioned the inception and institutionalization of sociology from the early postwar phase to German reunification. In this regard, I adopted the Bourdieusian concept of field as an analytical category for better framing the interdependence between the political and sociological fields, taking into account different collective and individual actors, their structural constraints and spaces of action in the construction of sociological knowledge. Departing from this viewpoint, I first questioned the possibility of interpreting the relationships between politics and sociology by a textual analysis. I argued, therefore, how this kind of reading may lead to 'tautological results' if separated from a broader analysis of the social structures of the sociological field and of the wider field of SSH-disciplines. I then claimed that a textual analysis may encourage an erroneous perception of the relationship between sociologists and the political apparatus, focusing mostly on ideological influences. What I instead argued is that the fact that processing sociological work was a political matter meant first that it required a set of routinized practices and a large number of people interrelated with each other through different formal and informal (hierarchical) social structures crossing both the political and the academic/scientific fields.

Following these considerations was also pivotal for reworking a further central question in studying the institutional, social, cultural and epistemic development of sociology in a dictatorial context, namely the question of its scientific autonomy. In this regard, the detection and analysis of the different institutionalization processes of sociological knowledge highlighted how the inception and development of the discipline were not only consequences of political decisions driven from the top. A further crucial aspect to take into account was the continuous rebuilding of a hierarchy of SS-disciplines which followed both pragmatic and ideological criteria. As a result, if on the one hand, scientific autonomy in the GDR was limited by its subordination 
to new ideological SS-disciplines, on the other hand it was partially relieved of (re) producing ideological statements. In this regard, sociology developed mainly as an applied SS-discipline, devoted to providing empirical findings.

Furthermore, if we take into account the complex and dynamic relationships between sociologists and the political apparatus as mediated by organizations, institutions and more or less formalized research groups, we can see how the degree of the politicization of sociological knowledge changed according to variables such as: the type of research institutes (scientific, academic or political), geographical closeness to Berlin (i.e., to the political centre of decision-making), the academic position and scientific (international) reputation of a sociologist within both the political and academic/scientific fields.

A final important point that I have only partially addressed concerns the development of sociological theories. As my interview partners emphasized, 'sociological theory' remained, de facto, 'à la carte'. Thus, their main difficulty in researching was to connect their empirical findings with the required ideological principles in the absence of theories and sociological concepts which could at least mediate between ideological values and empirical findings. Nevertheless, one of the more common strategies adopted by sociologists was to reformulate Western sociological concepts (the 'Western' concepts of 'role' or 'everyday life') in a language which could be politically accepted.

FUNDING: This research received no external funding.

CONFLICTS OF INTEREST: The author declares no conflict of interest.

ACKNOWLEDGEMENTS: I would like to thank the Zentrum Marc Bloch Centre in Berlin which hosted me during the empirical research in 2017 and the Institute of Sociology which hosted me the previous year.

\section{REFERENCES}

AA.VV. 1981a. "Kulturgeschichtliche Probleme Proletarischer Lebensweise. Mitteilungen aus der kulturwissenschaftlichen Forschung 9.

AA.VV. 1981b. "Formen der Individualität.” Mitteilungen aus der Kulturwissenschaftlichen Forschung 11.

AA.VV. 1988. Soziologie und Sozialpolitik. Berlin: Akademie der Wisssenschaft der DDRAdler, Frank, Jetzschmann, Horst and Albrecht Kretzschmar. 1977. Arbeiterklasse und Persönlichkeit im Sozialismus. Berlin: Dietz Verlag.

Adler, Frank and Rolf Reißig. 1991. "Sozialwissenschaftliche Forschung als 'Modernisierungs-Ferment' des Realsozialismus - eine gescheiterte Illusion?.” Wissenschaftliche Mitteulungen aus dem Berliner Instituts für Sozialwissenschaftliche Studien 4: 5-37.

Autorenkollektiv. 1975. Kulturelle Bedürfnisse der Arbeiterklasse. Berlin: Verlag Tribüne. Autorenkollektiv. 1985. Konservative Gesellschaftsstrategie - soziologisch begründet. Berlin: Dietz Verlag. 
Baert Patrick and Alan Shipman (2011) “Transforming the Intellectual.” Pp. 179-204 In The Politics of Knowledge edited by F. Dominguez Rubio F and P. Baert. London: Routledge.

Bafoil, François. 1991. “A quoi servait la sociologie en RDA.” Revue français de sociologie XXXII: 263-284.

Begemann, Herbert W. 1974. Kultursoziologie in der DDR. Erlangen: Institut für Gesellschaft und Wissenschaft.

Bertram, Hans (edited by). 1997. Soziologie und Soziologen im Übergang. Opladen: Leske + Budrich.

Bisky, Lothar. 1980. Geheime Verführer. Geschäft mit Shows, Stars, Reklame, Horror, Sex. Berlin: Verlag Neues Leben.

Bohring, Günther and Kurt Braunreuther. 1965. Soziologie und Praxis. Berlin. Dietz Verlag.

Bollhagen, Peter. 1966a. Soziologie und Geschichte. Berlin: VEB Deutscher Verlag der Wissenschaften.

Bollhgen, Peter. 1966b. Soziologische Forschung - Grundsätze und Methoden. Berlin: VEB Deutscher Verlag der Wissenschaften.

Boring, Günther and Horst Taubert (edited by). 1970. Sociological Research in the German Democratic Republic. Berlin: VEB Deutscher Verlag der Wissenschaften.

Bourdieu, Pierre. 1966. "Champ intellectuel et projet créateur." Les temps modernes 246: 865-905.

Bourdieu, Pierre. 1975. "The specificity of the Scientific Field and the Social Condition of the Progress of Reason.” Social Science Information 14(6): 19-47. DOI 10.1177/053901847501400602.

Bourdieu, Pierre. 1984. Homo Academicus. Paris: Editions de Minuit.

Bourdieu, Pierre. 1985. “The Markets of Symbolic Goods.” Poetics 14: 13-44, DOI: 10.1016/0304-422X(85)90003-8.

Bourdieu, Pierre. 1994. Raisons Pratiques. Paris: Du Seuil.

Bourdieu, Pierre. 2000. Propos sur le champ politique. Lyon: Presse universitaire de Lyon.

Bourdieu, Pierre. 2001. Science de la Science et réflexivité. Paris: Raison d'agir.

Bourdieu, Pierre. 2002. "Les conditions sociales de la circulation international des idées." Actes de la Recherche: 3-8.

Bourdieu, Pierre and Luc Boltanski. 2008. La production de l'idéologie dominante. Paris: Editions Raison d'agir.

Bourdieu Pierre, Chamboredon Jean-Claude and Jean-Claude Passeron. 1968. Le Métier du sociologue. Paris: Mouton et Bordas.

Bourdieu, Pierre and Loïc Wacquant. 1992. “The Logic of Fields.” Pp.: 115-140 in An Invitation to Reflexive Sociology, edited by P. Bourdieu and L. Wacquant. Chicago: University of Chicago Press.

Bradter, Wolfgang. 1976. Moral - Motiv - Verhalten. Berlin: VEB Deutscher Verlag der Wissenschaften.

Braunreuther, Kurt. 1962. Zur Kritik der bürgerlichen Soziologie in Westdeutschland. Berlin: VEB Deutscher Verlag der Wissenschaften. 
Brown, Richard H. 1993. "Modern Science: Institutionalization of Knowledge and Ratioalization of Power.” The Sociological Quarter 34(1): 153-168. Jugend im Osten. Köln: Zentralarchiv für Empirische Sozialforschung.

Burrichter, Clemens and Diesener, Gerald (edited by). 2002. Auf dem Weg zur Produktivkraft Wissenschaft. Leipzig: Akad. Verl.-Anst.

Camic Charles. 1992. Reputation and Predecessor Selection: Parsons and the Institutionalists. American Sociological Review 4: 421-445. DOI: 10.2307/2096093

Camic, Charles, Gross, Neil and Michele Lamont. 2012. Social Knowledge in the Making. Chicago: University of Chicago Press.

Chapoulie, Jean-Michel. 2001. La tradition sociologique de Chicago. Paris: Seuil.

Chapoulie, Jean-Michel. 2009. "A Framework for the History of Social and Behavioral Sciences.” Sociologica 2-3. DOI: 10.2383/31363.

Collins Randall. 2011. "Who has been a successful Public Intellectual?” European Journal of Social Theory 4: 437-452. DOI: 10.1177/1368431011417929.

Crossley, Nick. 2010. "The Social World of the Network." Sociologica, 1. DOI: $10.2383 / 32054$.

Dölling, Irene. 1987. Individuum und Kultur. Berlin: Dietz Verlag.

Eichhorn, Wolfgang, Hahn, Erich, Heyden, Günter, Puschmann, Manfred, Schulz, Robert and Horst Taubert. 1969. Wörterbuch der marxistischen-leninistischen Soziologie. Berlin: Dietz Verlag.

Fleck, Christian, Karady Vitor and Matthias Duller (edited by). 2018. Shaping Human Science Disciplines: Institutional Developments in Europe and Beyond. London: Palgrave.

Friedrich, Walter and Hartmut Griese (edited by). 1991. Jugend und Jugendforschung in der DDR. Opladen: Leske+Budrich.

Friedrich, Walter, Förster, Peter and Starke, Kurt (edited by). 1999. Das Zentralinstitut für Jugendforschung Leipzig 1966-1999. Berlin: Edition Ost.

Friedrich, Walter and Achim Hoffmann. 1986. Berlin: VEB Deutscher Verlag der Wissenschaften.

Greenfeld, Liah. 1988. "Soviet Sociology and Sociology in the Soviet Union.” Annual Review of Sociology 14: 99-123.

Hechler, Daniel and Pasternack, Peer (edited by). 2015. “Ein Vierteljahrhundert später. Zur politischen Geschichte der DDR-Wissenschaft.” Die Hochschule, 24(1).

Klingemann, Carsten. 1996. Soziologie im Dritten Reich. Baden Baden: Nomos.

Koch, Thomas. 1986. Kulturarbeit und Regionalität. Berlin: Mitteilungen aus der kulturwissenschaftlichen Forschung.

Koch, Ursula. 1976. Bürgerliche und sozialistische Forschungsmethoden? Zur Rezeption empirischer Sozialforschung in der DDR. Frankfurt/M: Campus.

Koch, Ursula. 1997. “Dokumentation der 'Grauen Literatur' aus der DDR und osteuropäischer Jugendforschungsprojekte.” Pp. 47-54 in Jugend im Osten. Sozialwissenschaftliche Daten und Kontextwissen aus der DDR sowie den neuen Bundesländern (1969-1995) edited by E. Brissinger; B. Hausstein and E. Riedel. Berlin: Trafo Verlag.

Kretzchmar, Albert and Rudi Weidig (edited by). 1990. “Zum 5. Kongress der Soziologie 
in der DDR.” Deutsche Zeitschrift für Philosophie 38(1).

Kuczynski, jürgen. 1987. Die Intelligenz: Studien zur Soziologie und Geschichte ihrer

Grossen. Berlin: Akademie Verlag.

Lepenies, Wolfgang. 1981. "Einleitung. Studien zur kognitiven, sozialen und historischen Identität der Soziologie.” Pp. 1-15 in Geschichte der Soziologie I, edited by W. Lepenies. Frankfurt/M: Suhrkamp.

Ludz, Peter C. 1971. “Soziologie und empirische Sozialforschung in der DDR.” Pp. 327418 in Studien und Materialien zur Soziologie der DDR, edited by P.C. Ludz. Opladen: Westdeutscher Verlag.

Ludz, Peter C. (edited by). 1972. Soziologie und Marxismus in der Deutschen Demokratischen Republik. Neuwied und Berlin: Luchterhand.

Luhmann, Niklas. 1997. Die Gesellschaft der Gesellschaft. Frankfurt/M: Suhrkamp.

Meier, Arthur. 1974. Soziologie des Biludngswesens. Berlin: Volk und Wissen.

Moody, James. 2004. "The Structure of a Social Science Collaboration Network-Disciplinary Cohesion from 1963 to 1999." American Sociological Review 69(2): 213238. DOI: $10.1177 / 000312240406900204$.

Nolepa, Gerda and Lilo Steitz. 1975. Wissenschaftlich-technischer Fortschritt - Arbeiterklasse - Schöpfertum. Berlin: Dietz Verlag.

Pasternack, Peer. 2016. Die DDR-Gesellschaftswissenschaften Postmortem: ein Vierteljahrhundert Nachleben (1990-2015). Berlin: Berlin-Wissenschaftsverlag.

Peter, Lothar. 1991. Dogma oder Wissenschaft? Marxistisch-leninistische Soziologie und Staatssozialistisches System in der DDR. Frankfurt/M: IMSF.

Petzoldt, Gerlinde. 1988. Erforschung des Freizeitverhaltens in der DDR und der Sowjetunion. Berlin: Mitteilungen aus der kulturwissenschaftlichen Forschung.

Polgers, Uta G. 2000. Jazz, Rock and Rebels. Cold War Politics and American Culture in a Divided Germany. Berkeley and Los Angels: University of California Press.

Rammstedt, Otthein. 1986. Deutsche Soziologie 1933-1945. Frankfurt/M: Suhrkamp.

Ringer Fritz. 1990. "The Intellectual Field, Intellectual History, and the Sociology of Knowledge.” Theory and Society 3: 269-294. DOI: 10.1007/BF00149840

Santoro, Marco. 2013. "Empire for the Poor. Imperial Dreams and the Quest for an Italian Sociology 1870s - 1950s.” Pp. 106-165 in Sociology \& Empire edited by G. Steinmetz. Durham/London: Duke University Press.

Santoro, Marco, Andrea Gallelli, and Barbara Grüning. 2018. "Bourdieu's international circulation. An exercise in intellectual mapping.” Pp. 21-67 in The Oxford Handbook of Bourdieu, Oxford, edited by, T. Medvev and J. Sallaz. Oxford: Oxford University Press.

Schäfers, Bernhard (edited by). 1995. Soziologie in Deutschland. Entwicklung, Institutionalisierung und Berufsfelder Theoretischer Kontroversen. Opladen: Leske + Budrich.

Schmickl, Emil. 1973. Soziologie und Sozialismus Theorie in der DDR. Köln: Verlag Wissenschaft und Politik.

Sparschuh, Vera. 1991. “From Orthodoxy to Conservatorism: Which Path will Sociology take in the GDR?” Canadian Journal of Sociology 16(1): 79-82.

Sparschuh, Vera and Ute Koch. 1997. Sozialismus und Soziologie. Opladen: Leske+Budrich. 
Sparschuh, Vera and Dagmar Simon. 1992. Der Nachlaß der DDR-Soziologie - bloßes Archivmaterial oder soziologisches Forschungsfeld? WZB Bibliothek.

Steinmetz, Georg. 2017. "Field Theory and Interdisciplinarity: History and Sociology in Germany and France during the Twentieth Century." Comparative Studies in Society and History 59(2): 477-514. DOI: 10.1017/S0010417517000111.

Steiner, Helmut. 1997. “Aufbruch, Defizite und Leistungen der DDR-Soziologie.” Pp. 223-304 in Soziologie und Soziologen im Übergang, edited by H. Bertram. Opladen: Leske+Budrich.

Steiner, Helmut. 2010. Klassengesellschaft im Umbruch: Soziale Mobilitätsprozesse in der DDR-Gesellschaft. Berlin: Sigma.

Timmerman, Heiner. 1990. Lebenslagen. Sozialindikatorenforschung in beiden Teilen Deutschlands. Saarbrücken-Scheidt: Dadder.

Wagner, Karl. 1989. “Zwischen Vernachlässigung und Akzeptanz? Zu Problemen aktueller Berücksichtigung der DDr-Soziologie durch 'die’ westdeutsche Soziologie.” Soziale Welt 1/2: 142-167.

Weidig, Rudig. 1997. Soziologische Forschung in the DDR. Einige Aspekte der Arbeit des Wissenschaftlichen Rates. WZB Bibliothek.

Weissel, Bernhard (edited by). 1980. Kultur und Ethnos. Zur Kritik der bürgerlichen Auffassungen über die Rolle der Kultur in Geschichte und Gesellschaft. Berlin: Akademie Verlag.

Wehling, Hans-Georg (edited by). 1989. Politische Kultur in der DDR. Stuttgart: Kohlhammer.

Weymann, Ansgar. 1972. Gesellschaftswissenschaften und Marxismus. Dusseldorf: Bertelsmann Universitätsverlag.

Whitley, Richard. 1974. "Cognitive and social institutionalization of scientific specialities and research areas.” Social Processes of Scientific Development: 65-95.

Wicke, Peter. 1987. Rockmusik. Zur Ästhetik und Soziologie eines Massenmediums. Leipzig: Reclam.

Wiedemann, Dieter and Eckard Griebel. 1980. Film - Jugend - Freizeit. Zentralhaus für Kulturarbeit der DDR.

Wiedemann, Dieter. 1983. Zur sozialen Funktion des Kinos in den achtziger Jahren. Babelsberg: Betriebsakademie des VEB DEFA Studio für Spielfilme.

Zentralhaus für Kulturarbeit der DDR. 1978. Wissenschaftliche Beiträge 9.

\section{BIOGRAPHICAL NOTE}

Barbara Grüning is an assistant professor in Cultural Sociology at the University of Milan Bicocca, Italy.

OPEN ACCESS: This article is distributed under the terms of the Creative Commons Attribution Non-commerical License (CC BY-NC 4.0) which permits any noncommercial use, and reproduction in any medium, provided the original author(s) and source are credited. 


\section{APPENDIX}

Table 1. The institutionalization of sociology in the GDR

\begin{tabular}{|c|c|c|c|c|c|c|c|c|}
\hline Year & Place & $\begin{array}{l}\text { Poll/ } \\
\text { Acad/ } \\
\text { Sc. }\end{array}$ & Institutes & Councils & $\begin{array}{l}\text { D e - } \\
\text { gree-cours- } \\
\text { es }\end{array}$ & Sections & $\begin{array}{l}\mathrm{R} \text { e - } \\
\text { search } \\
\text { groups }\end{array}$ & Subjects \\
\hline \multirow[t]{4}{*}{1946} & $\begin{array}{l}\text { Phil. Fak, HU Ber- } \\
\text { lin }\end{array}$ & A & & & & & & $\begin{array}{l}\text { Phil.u. Sozi- } \\
\text { ol. }\end{array}$ \\
\hline & $\begin{array}{l}\text { Päd ag o g i s c he } \\
\text { Fakultäten }\end{array}$ & A & $\begin{array}{l}\text { Kultur- u. } \\
\text { Bildungs- } \\
\text { soziol. }\end{array}$ & & & & & \\
\hline & $\begin{array}{l}\text { Päd a g o g i s che } \\
\text { F a k u l t ä t e n, } \\
\text { Leipzig; Dresden }\end{array}$ & A & & & & & & Soziologie \\
\hline & $\begin{array}{l}\text { Päd a g o g i s c he } \\
\text { Fakultäten }\end{array}$ & A & & & & & & $\begin{array}{l}\text { Psychologie } \\
\text { und Sozi- } \\
\text { ologie der } \\
\text { lehrberuge; } \\
\text { Soziologie }\end{array}$ \\
\hline 1947 & $\begin{array}{l}\text { G e s e } 11 \mathrm{~s} \mathrm{c} \mathrm{h} \text {. } \\
\text { Fakultät, Rostock }\end{array}$ & A & $\begin{array}{l}\text { I. für Soziol. } \\
\text { u. Gesch.d. } \\
\text { sozial. Be- } \\
\text { weg. }\end{array}$ & & & & & \\
\hline 1948 & $\begin{array}{l}\text { Psychol. Fakultät, } \\
\text { Potsdam }\end{array}$ & A & & & & & & Soziologie \\
\hline \multirow[t]{3}{*}{1949} & $\begin{array}{l}\text { Fak. Finanzwiss. } \\
\text { Rostock }\end{array}$ & A & & & & & & $\begin{array}{l}\text { Allg. Sozi- } \\
\text { o l o g i e ; } \\
\text { Rechts- u. }\end{array}$ \\
\hline & $\begin{array}{l}\text { I. für pol. u. soz. } \\
\text { Probleme, } \\
\text { Berlin }\end{array}$ & A & & & & & & Soziologie \\
\hline & $\begin{array}{l}\text { G e s e } 11 \mathrm{~s} \mathrm{c} \mathrm{h} \text {. } \\
\text { Fakultät, Leipzig }\end{array}$ & A & & & & & & $\begin{array}{l}\text { Rechtssozi- } \\
\text { ologie }\end{array}$ \\
\hline 1950 & $\begin{array}{l}\text { Jena, Ge- } \\
\text { sellschaftliche } \\
\text { Fak. }\end{array}$ & A & & & & & & $\begin{array}{l}\text { Kultursozi- } \\
\text { ologie }\end{array}$ \\
\hline & $\begin{array}{l}\text { G e s e } 11 \mathrm{~s} \mathrm{c} \mathrm{h} \text {. } \\
\text { Fakultät, Rostock }\end{array}$ & A & & & & & & $\begin{array}{l}\text { Soziolog. } \\
\text { Obersemi- } \\
\text { nar }\end{array}$ \\
\hline
\end{tabular}

1951 II University reform -> centralization and planning of the university system [five-year plans]; introduction of the 'Gesellschaftswissenschaftlichen' basic studies in every degree-course; Foundation of the Institut für Gesellschaftswissenschaften (ab 1976 'Akademie’)

\begin{tabular}{|l|l|l|l|l|l|l|l|l|}
\hline 1952 & & & & & & & & \\
\hline 1953 & & & & & & & & \\
\hline
\end{tabular}




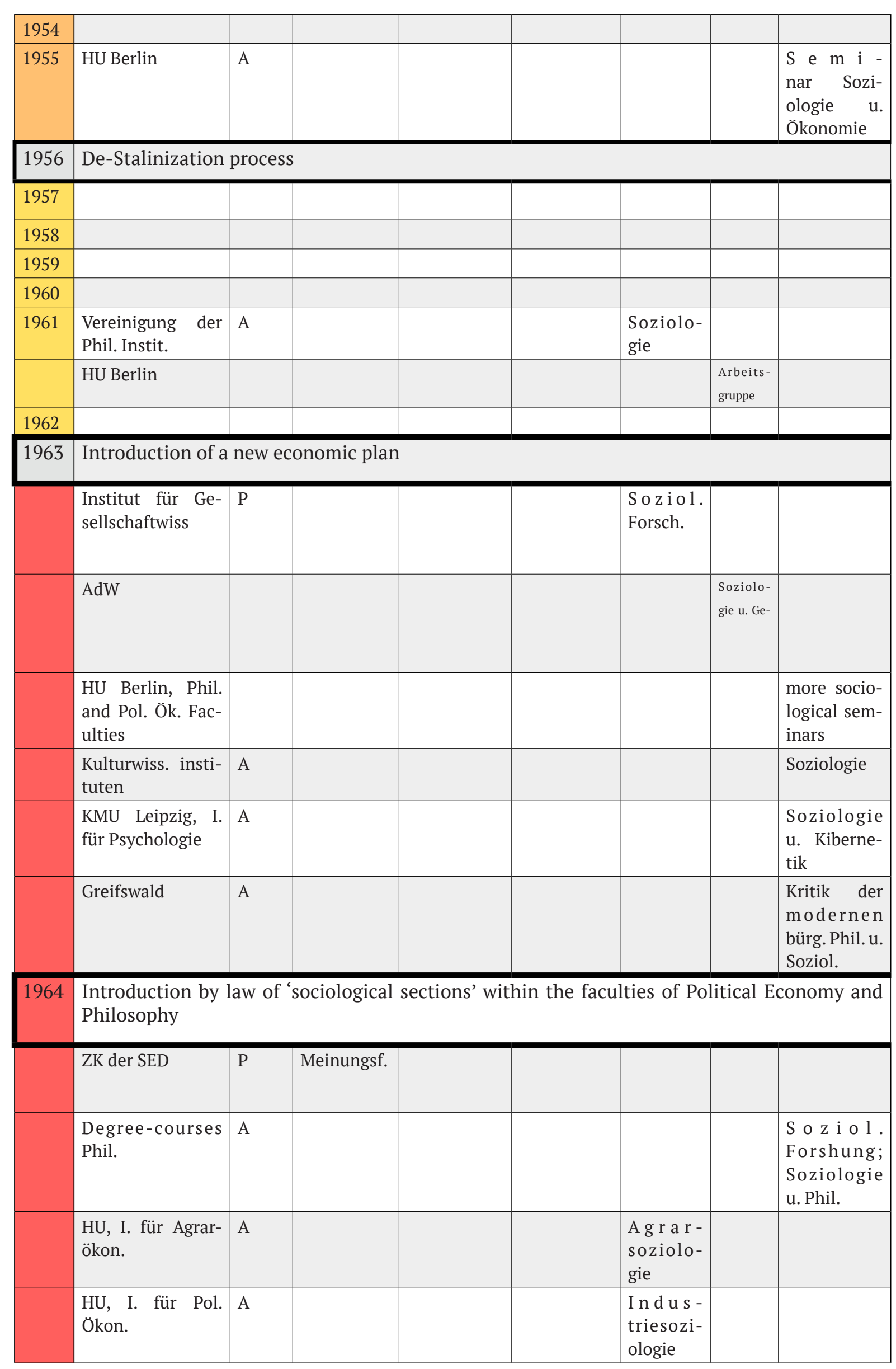




\begin{tabular}{|c|c|c|c|c|c|c|c|c|}
\hline & $\begin{array}{l}\text { HU, Fakultät } \\
\text { Wirtschaftsw. }\end{array}$ & A & & & $\begin{array}{l}\text { post-degree } \\
\text { certificate }\end{array}$ & & & \\
\hline & $\begin{array}{l}\text { MLU, Halle, } \\
\text { I. für Staats- } \\
\text { bürgerkunde }\end{array}$ & A & & & & & & $\begin{array}{l}\text { S o c i o } 1 \text { o- } \\
\text { gische For- } \\
\text { schung }\end{array}$ \\
\hline & $\begin{array}{l}\text { KMU, D.c. Kultur- } \\
\text { wissenschaften }\end{array}$ & A & & & & & & Soziologie \\
\hline & $\begin{array}{l}\text { HU, I. für Musik- } \\
\text { wiss. }\end{array}$ & A & & & & & & $\begin{array}{l}\text { Soziologie; } \\
\text { Musiksozi- } \\
\text { ologie }\end{array}$ \\
\hline & AdW & S & & Die Frau & & & & \\
\hline & AdW & $S$ & & & & & $\begin{array}{l}\text { D i e } \\
\text { Frau }\end{array}$ & \\
\hline \multirow[t]{5}{*}{1965} & \multicolumn{8}{|c|}{ Introduction by law of a central program for sociological research } \\
\hline & $\begin{array}{l}\text { Institut für Ge- } \\
\text { sellschaftwiss }\end{array}$ & $\mathrm{P}$ & & $\begin{array}{l}\text { wiss. Rat } \\
\text { für soziol. } \\
\text { Forsch. }\end{array}$ & & & & \\
\hline & $\begin{array}{l}\text { Institut für Ge- } \\
\text { sellschaftwiss/ } \\
\text { Fachr. Kultur }\end{array}$ & $\mathrm{P}$ & & & & & $\begin{array}{l}\text { K u l - } \\
\text { t u r - } \\
\text { s o z i - } \\
\text { ologie }\end{array}$ & \\
\hline & $\begin{array}{ll}\text { KMU, } & \text { Phil. } \\
\text { Fakultät } & \\
\end{array}$ & A & & & & $\begin{array}{l}\text { Soziolo- } \\
\text { gie }\end{array}$ & & \\
\hline & $\begin{array}{l}\text { Deutsch Päd. In- } \\
\text { stitute }\end{array}$ & $S$ & & & & $\begin{array}{l}\text { Soziol. d. } \\
\text { Bildung- } \\
\text { swesens }\end{array}$ & & \\
\hline 1966 & Leipzig & $S$ & $\begin{array}{l}\text { Jugendfor- } \\
\text { schung }\end{array}$ & & & & & \\
\hline \multirow[t]{3}{*}{1967} & MLU Halle & A & & & & $\begin{array}{l}\text { Soziolo- } \\
\text { gie }\end{array}$ & & \\
\hline & AdW & $S$ & & & & & Soziol. & \\
\hline & Hochschule KMS & A & & & & $\begin{array}{l}\text { Soziolo- } \\
\text { gie }\end{array}$ & & \\
\hline 1968 & $\begin{array}{l}\text { degree-courses } \\
\text { Phil. \& Pol.Ök }\end{array}$ & A & & & & & & $\begin{array}{l}\text { secundary } \\
\text { sub. }\end{array}$ \\
\hline \multicolumn{9}{|l|}{1969} \\
\hline \multirow[t]{2}{*}{1970} & \multicolumn{8}{|c|}{$\begin{array}{l}\text { The third university reform reinforced the position of the 'Gesellschaftswissenschaften' with- } \\
\text { in the academic system and the hierarchy of academic disciplines, according to the decision } \\
\text { of Politbüros (1968) }\end{array}$} \\
\hline & AdW & $S$ & & $\begin{array}{l}\text { National- } \\
\text { komitee }\end{array}$ & & & & \\
\hline 1971 & \multicolumn{8}{|c|}{$\begin{array}{l}\text { New economic model 'Unity of economic and social politics' -> social politics becomes a cen- } \\
\text { tral instrument for increasing the material and cultural life of the GDR population }\end{array}$} \\
\hline
\end{tabular}




\begin{tabular}{|c|c|c|c|}
\hline & HU, KMU; MLU & A & $\begin{array}{l}\text { Fachausbil- } \\
\text { dung/spe- } \\
\text { cialization }\end{array}$ \\
\hline \multicolumn{4}{|l|}{1972} \\
\hline \multicolumn{4}{|l|}{1973} \\
\hline 1974 & Refor & & \\
\hline
\end{tabular}

\begin{tabular}{|c|c|c|c|c|c|c|}
\hline & ZK der SED & $P$ & & $\begin{array}{l}\text { wiss. Rat für } \\
\text { Sozialpoli- } \\
\text { tik }\end{array}$ & & \\
\hline \multirow[t]{3}{*}{1975} & $\begin{array}{l}\text { * Institut für Ge- } \\
\text { sellschaftwiss }\end{array}$ & $\mathrm{P}$ & $\begin{array}{l}\text { I. für ML - } \\
\text { Soziologie }\end{array}$ & & & \\
\hline & $\begin{array}{l}\text { Institut für Ge- } \\
\text { sellschaftwiss }\end{array}$ & $\mathrm{P}$ & $\begin{array}{l}\text { I. für So- } \\
\text { zialpolitik }\end{array}$ & & & \\
\hline & HU, KMU; MLU & A & & & aut. d.c. & \\
\hline \multicolumn{7}{|l|}{1976} \\
\hline \multicolumn{7}{|l|}{1977} \\
\hline 1978 & AdW & $\mathrm{S}$ & $\begin{array}{l}\text { I. für Sozi- } \\
\text { ologie u. } \\
\text { Sozialpoli- } \\
\text { tik }\end{array}$ & & & \\
\hline 1979 & ZK der SED & $\mathrm{P}$ & $\begin{array}{l}+ \text { I. für } \\
\text { Meinungs- } \\
\text { forschung }\end{array}$ & & & \\
\hline & $\mathrm{HU}$ & A & $\begin{array}{l}\text { I. für ML - } \\
\text { Soziologie }\end{array}$ & & & \\
\hline 1980 & HU, Kulturwiss. & A & & & & $\begin{array}{l}\text { Kultursozi- } \\
\text { ologie }\end{array}$ \\
\hline & HU, Ber. Medizin & & & & & Soziologie \\
\hline
\end{tabular}

1981 Reform of the curricula, planned 1990 -> it followed the new central research plan (1980) for the ML studies of society, established by the ZK of the SED

\begin{tabular}{|l|l|l|l|l|l|l|l|}
\hline 1982 & $\begin{array}{l}\text { Ministerium f. P } \\
\text { Hoch- u. Fach- } \\
\text { schulwesen }\end{array}$ & $\begin{array}{l}\text { wiss. Beirat } \\
\text { für ML Sozi- } \\
\text { ologie }\end{array}$ & & & & \\
\hline
\end{tabular}

Source: Documents collected by the Bundesarchiv and the Humboldt-Universitätsarchiv in Berlin (see footnotes in the last paragraph). 
Table 2. Sociology conferences and sociological journals in the GDR

\begin{tabular}{|c|c|c|c|c|}
\hline \multirow[t]{2}{*}{ YEAR } & \multicolumn{3}{|l|}{ CONFERENCES } & \multirow{2}{*}{$\begin{array}{l}\text { JOURNALS / } \\
\text { Bookseries }\end{array}$} \\
\hline & LOCAL & NATIONAL & INTERNATIONAL & \\
\hline 1956 & & & ISA (invited) & \\
\hline 1959 & & & ISA (invited) & \\
\hline 1962 & $\begin{array}{l}\text { Prieros, Research group } \\
\text { 'Soziologie u. Geselschaft' }\end{array}$ & & & \\
\hline 1963 & $\begin{array}{l}\text { Berlin, Research group 'Sozi- } \\
\text { ologie u. Geselschaft' }\end{array}$ & & & $\begin{array}{l}\text { Religionssozi- } \\
\text { ologische Bul- } \\
\text { letin der Uni- } \\
\text { versität Jena }\end{array}$ \\
\hline 1964 & $\begin{array}{l}\text { Merseburg, Research group } \\
\text { 'Soziologie u. Geselschaft' }\end{array}$ & & & $\begin{array}{l}\text { Informationen } \\
\text { zur soziolo- } \\
\text { gischen For- } \\
\text { schung in der } \\
\text { DDR (Akademie } \\
\text { der Ges.Wiss.) }\end{array}$ \\
\hline 1965 & $\begin{array}{l}\text { Halle, I. of literary studies } \\
\text { 'Literatursoziologie' }\end{array}$ & & $\begin{array}{l}\text { Jena, Int. conf. sociol- } \\
\text { ogy of religion in the } \\
\text { socialist countries }\end{array}$ & $\begin{array}{l}\text { Dietz Verlag } \\
\text { b o o k s e r i e s } \\
\text { 'Soziologie' }\end{array}$ \\
\hline & & & & $\begin{array}{l}\text { Soziologische } \\
\text { Bulletin (Wiss. } \\
\text { Rat) }\end{array}$ \\
\hline & $\begin{array}{l}\text { Leipzig, workshop 'youth and } \\
\text { technology' }\end{array}$ & & & \\
\hline 1966 & $\begin{array}{l}\text { Leipzig, JFZ, workshop 'youth } \\
\text { and technology' }\end{array}$ & & ISA (14 participants) & $\begin{array}{l}\text { internationale } \\
\text { Berichte über } \\
\text { Religionssozio- } \\
\text { logie }\end{array}$ \\
\hline & & & $\begin{array}{l}\text { Int. Colloquium on } \\
\text { workers' movement } \\
\text { (K: raunreuther) }\end{array}$ & \\
\hline 1967 & $\begin{array}{l}\text { Leipzig, JFZ, workshop 'youth } \\
\text { and technology' }\end{array}$ & $\begin{array}{l}\text { Dresden, organized by the } \\
\text { scientific council for socio- } \\
\text { logical r. }\end{array}$ & & $\begin{array}{l}\text { Periodikum Ju- } \\
\text { gendforschung }\end{array}$ \\
\hline 1969 & & GDR- sociological congress & & \\
\hline 1970 & & & ISA (54 participants) & \\
\hline 1972 & & & & $\begin{array}{l}+ \text { Periodikum } \\
\text { J u g e } n \text { d f o r }- \\
\text { schung }\end{array}$ \\
\hline 1974 & & GDR- sociological congress & ISA (12 participants) & \\
\hline 1978 & & & ISA (15 participants) & \\
\hline
\end{tabular}




\begin{tabular}{|c|c|c|c|c|}
\hline 1980 & & GDR- sociological congress & & $\begin{array}{l}\text { Jahrbuch für } \\
\text { Soziologie und } \\
\text { Sozialpolitik, } \\
\text { AdW }\end{array}$ \\
\hline 1982 & & & ISA (4 participants) & $\begin{array}{l}\text { Book series } \\
(\text { AdW): Sozi- } \\
\text { ologie und So- } \\
\text { zialpolitik }\end{array}$ \\
\hline 1985 & & GDR- sociological congress & & \\
\hline 1986 & & & ISA (9 participants) & \\
\hline 1987 & & & & $\begin{array}{l}\text { B o o k- s e ri e s } \\
\text { (AdW): Sympo- } \\
\text { sien und Kollo- } \\
\text { quien }\end{array}$ \\
\hline 1989 & $\begin{array}{l}\text { Seminar at the HU with Bour- } \\
\text { dieu }\end{array}$ & & & \\
\hline 1990 & & $\begin{array}{l}\text { GDR- sociological congress } \\
\text { co-organized by the initia- } \\
\text { tive group for the founda- } \\
\text { tion of a Sociological Assoc. }\end{array}$ & & $\begin{array}{l}\text { Berliner Journal } \\
\text { für Soziologie } \\
\text { (Fall) }\end{array}$ \\
\hline
\end{tabular}

Source: Documents collected by the Bundesarchiv, the Humboldt-Universitätsarchiv and the Staatsbibliothek in Berlin (see footnotes in the last paragraph). 
Table 3a. Philosophical curriculum with specialization in sociology, 1975

\begin{tabular}{|c|c|c|}
\hline SUBJECT & & HOURS \\
\hline Introduction to ML Sociology & & 32 \\
\hline Dialectical Materialism & & 128 \\
\hline Historical Materialism & & 128 \\
\hline Political Economy of Capitalism & & 128 \\
\hline Political Economy of Socialism & & 128 \\
\hline Scientific Communism & & 90 \\
\hline Seminar on the Classics of ML & & 128 \\
\hline $\begin{array}{l}\text { History of the German Labour Movement and of the } \\
\text { German Nation (Volk) }\end{array}$ & & 64 \\
\hline History of the Soviet Communist Party & & 64 \\
\hline \multirow[t]{4}{*}{ History of Philosophy } & Ancient Phil. & 96 \\
\hline & Modern Phil. & 144 \\
\hline & ML Philosophy & 208 \\
\hline & $\begin{array}{l}\text { Modern Bourgeois Phil. and Soci- } \\
\text { ol. }\end{array}$ & 152 \\
\hline Seminar (advanced) on Dialectical Materialism & & 30 \\
\hline ML Ethics & & 90 \\
\hline ML Aesthetics & & 30 \\
\hline Logic & & 160 \\
\hline Seminar (advanced) on Problems of Socialism & & 356 \\
\hline Mathematics and Statistics & & 188 \\
\hline Psychology & & 60 \\
\hline Theory of ML Sociology & & 120 \\
\hline History of Sociology & & 114 \\
\hline Special Topics in Sociology & & 286 \\
\hline Sociology of Work and Industry & & 92 \\
\hline Methodology of Sociological Research & & 136 \\
\hline Specialization & & 380 \\
\hline Russian & & 192 \\
\hline 2nd Foreign Language & & 80 \\
\hline Sport & & 316 \\
\hline Propagandistic Activities & & 64 \\
\hline Gesellschaftswiss. Disciplines & & 888 \\
\hline Philosophy & & 880 \\
\hline Sociology & & 780 \\
\hline Specialization & & 380 \\
\hline Other disciplines & & 520 \\
\hline Sport & & 316 \\
\hline Propagandistic Activities & & 64 \\
\hline
\end{tabular}

Source: Ministerium für Hoch- und Fachschulwesen: 'Studienplan für die Richtung Marxistisch-leninistische Soziologie', Berlin 1975 
Table 3b. Philosophical curriculum with specialization in sociology, 1982

\begin{tabular}{|c|c|c|}
\hline SUBJECT & & HOURS \\
\hline Introduction to ML Sociology & & 30 \\
\hline Dialectical Materialism & & 120 \\
\hline Historical Materialism & & 120 \\
\hline \multirow[t]{3}{*}{ Political Economy } & of Capitalism & 90 \\
\hline & of Socialism & 90 \\
\hline & Seminar on the Classics of ML & 90 \\
\hline Scientific Communism & & 90 \\
\hline $\begin{array}{l}\text { History of the SED and of the International La- } \\
\text { bour Movement }\end{array}$ & & 120 \\
\hline History of Philosophy & & 375 \\
\hline \multirow[t]{3}{*}{ Mathematics, Statistics, Informatics } & Mathematics & 60 \\
\hline & Statistics & 105 \\
\hline & Iinformatics & 30 \\
\hline \multirow[t]{2}{*}{ Theory of Sociology } & & 90 \\
\hline & Special Seminars & 30 \\
\hline \multirow[t]{2}{*}{ History of Sociology } & & 90 \\
\hline & $\begin{array}{l}\text { Critique of the Current Bourgeois Sociol- } \\
\text { ogy }\end{array}$ & 30 \\
\hline \multirow[t]{2}{*}{ Methodology and Methods of Sociology } & & 180 \\
\hline & Special Seminars & 30 \\
\hline \multirow[t]{4}{*}{ Secondary Sociological Topics (obligatory) } & $\begin{array}{l}\text { Sociology of Work, Industry and Corpora- } \\
\text { tions (Sociology of Organizations) }\end{array}$ & 120 \\
\hline & Special Seminars & 30 \\
\hline & Urban Sociology & 30 \\
\hline & ML Military Sociology & 15 \\
\hline \multirow[t]{7}{*}{ Secondary Sociological Topics (choice) } & & 120 \\
\hline & Sociology of Family & \\
\hline & Cultural Sociology & \\
\hline & Sociology of Education & \\
\hline & Sociology of Youth & \\
\hline & Sociology of Agriculture & \\
\hline & others & \\
\hline Research Seminars & & 150 \\
\hline Specialization & & 60 \\
\hline \multirow[t]{3}{*}{ General Psychology } & & 30 \\
\hline & Social Psychology & 30 \\
\hline & Work Psychology & 30 \\
\hline Social Politics & & 30 \\
\hline Demography & & 30 \\
\hline Logic & & 60 \\
\hline Activities Devoted to the Section & & 120 \\
\hline Russian & & 180 \\
\hline
\end{tabular}




\begin{tabular}{|l|c|c|}
\hline 2nd Foreign Language & & 75 \\
\hline Sport & & 286 \\
\hline Gesellschaftsdisziplinen & & 720 \\
\hline Philosophical Studies & & 435 \\
\hline Sociological Studies & & 1205 \\
\hline Specialization & & 60 \\
\hline Other Disciplines & & 600 \\
\hline Activities Devoted to the Section & & 120 \\
\hline Sport & & 286 \\
\hline
\end{tabular}

Source: Ministerium für Hoch- und Fachschulwesen, with attached 'Lehrprogramm für das Lehrgebiet. Informationsverarbeitung zur Ausbildung in der Fachrichtung Marxistisch-leninistische Soziologie', in Archiv, 17th March 1982 
Table 3c. Sociological curriculum, HUB, 1987

\begin{tabular}{|c|c|c|}
\hline Disciplinary Areas & Disciplines/Subdisciplines & hours \\
\hline \multirow[t]{4}{*}{ Marxismus-Leninismus } & Philosophy & 150 \\
\hline & Political Economy & 180 \\
\hline & Scientific Communism & 90 \\
\hline & History of the SED & 60 \\
\hline Tot & & 480 \\
\hline \multirow[t]{4}{*}{ Further Basic Studies } & Mathematics & 50 \\
\hline & Statistics & 120 \\
\hline & Informatics & 60 \\
\hline & Optional & 60 \\
\hline Tot & & 290 \\
\hline \multirow[t]{9}{*}{ Sociological Disciplines } & Theory of Sociology & 180 \\
\hline & Methodology and Methods of Sociology & 170 \\
\hline & History Of Sociology & 120 \\
\hline & Critique of Current Bourgeois Sociology & 60 \\
\hline & Seminar: 'Sociological Classics’ & 45 \\
\hline & Sociology of Work, Industry and Management & 120 \\
\hline & Urban Sociology & 60 \\
\hline & ML Military Sociology & 15 \\
\hline & 1 Package To Choose & 120 \\
\hline \multirow[t]{4}{*}{$(1)$} & Sociology of Science & \\
\hline & Sociology of Education & \\
\hline & Sociology of Technology & \\
\hline & AIBS Seminar (Work, Industry, Management) & \\
\hline \multirow[t]{6}{*}{ (2) } & Sociology of Leisure & \\
\hline & Sociology of Youth & \\
\hline & Sociology of Family & \\
\hline & Sociology of Health & \\
\hline & Stage/Seminars & 30 \\
\hline & Application Seminars & 150 \\
\hline Tot & & 1070 \\
\hline \multirow[t]{2}{*}{ Economics } & Socialist National Economics & 75 \\
\hline & Socialist Business Management & 120 \\
\hline Tot & & 195 \\
\hline \multirow[t]{4}{*}{ Further Obligatory Subjects } & Russian & 120 \\
\hline & English & 120 \\
\hline & Sport & 270 \\
\hline & Data Protection (* Geheimnisschutz) & 15 \\
\hline Tot & & 525 \\
\hline \multirow[t]{4}{*}{ Further Subjects } & Foundations of Technology & 60 \\
\hline & Logic & 30 \\
\hline & Demography & 30 \\
\hline & Psychology & 60 \\
\hline
\end{tabular}




\begin{tabular}{|l|l|l|}
\hline Tot & & 180 \\
\hline Optional Subjects & & \\
\hline & History of Philosophy & \\
\hline & History of Economics & \\
\hline
\end{tabular}

Source: 'Leitlinien dem 1. Studienjahr 1987/1988 einsetzenden Studienplanexperiments für die Fachrichtung Soziologie an der HUB, Institute für marxistisch-leninistische Soziologie', Berlin, May 28th, 1987 